\title{
THE EARLIEST FRENCH REVIEW OF WHITMAN (CONTINUED)
}

The problem raised by Ezra Greenspan in his interesting article ("The Earliest French Review of Walt Whitman,"Walt Whitman Quarterly Review 6 [Winter 1989], 109-116), and raised again in his note printed above, is indeed very curious and quite baffling. In one of its last issues, the New York Saturday Press-whose editor, Henry Clapp, had always championed Whitman ${ }^{1}-$ printed the translation of an anonymous French article that had supposedly appeared in the Bibliographie Imperiale. The article announced the forthcoming publication of a French translation of the 1860 Leaves of Grass (less than six months after the appearance of the book in America-record time for a translation of a massive volume of poetry!), and it even quoted extracts from the preface by the translator and samples of the translation itself. The full name of the translator was not given, only his initials: V.H. Faithful readers of Whitman could find in this announcement ample reason for rejoicing-their poet was soon going to be known and appreciated in France. Unfortunately, the translation never appeared. The publisher whose name and address were given in the article did not exist, and the Bibliographie Imperiale, in which the original article was said to have appeared, did not exist either. The whole thing was a hoax, as any attentive reader could have guessed.

In fact, the preface itself contained some strange and rather suspicious statements. Poetry, according to V.H., is the daughter of the Imagination, but the name of the father is unknown, thus making Poetry a bastard child-not a very flattering portrayal. We are told besides that the "marriage" took place in the twenty-first "arrondissement" of Paris, where there are only twenty. The translator again tips his hand in the concluding paragraph of his introduction when he quotes from a non-existent comedy by Victor Hugo called "The Death of Abel"; the so-called quotation turns out to be merely a vulgar proverbial expression: "Let him whose nose runs blow it." Thus warned, we realize that the intermediate passage is also meant ironically and that V.H. is not really serious when he claims that perfect poetry should be incomprehensible and that the charm of the American poet derives from the fact that "the more you read, the less you understand." Whitman's fundamental aesthetic principle-that it is up to the reader to complete his poems - is rendered faintly ridiculous by V.H. when he claims that if "you do not understand the poem exactly, you share in the inspiration of the poet" and thus become "a partner in a great poetic venture."

Similarly, when we begin to read the quotations from the translated poems, they at first sound quite legitimate (even if "troupeau" in the second line is rather pejorative):

O mére! O fils!

Chants Démocratiques.

O troupeau continental!

O fleur des prairies!

O espace sans fin! O bourdonnements de produits puissants!

$\mathrm{O}$ villes grouillantes! si invincibles, si tumultueuses, si fières! 
It goes on like this for several lines. The translation is correct and even quite acceptable, but the last line of the paragraph gives the reader a jolt:

Eau de Javelle!

"Javel water!" corresponds to nothing in Whitman's text; here the translator is punning upon " $\mathrm{O}$," and it becomes obvious that he is retroactively ridiculing Whitman's accumulation of apostrophes. He winks at the reader to warn him that he has had his tongue in his cheek all the time.

In the same way, the translation of "Calamus 17" is at first quite serious, but is soon interspersed with jarring vulgarisms, one in particular: "Et maintenant je suis disposé à me ficher des cimetières. ..." This is roughly the equivalent of "And now I don't give a fuck about churchyards. . . ."

To a French reader, then, it is quite clear that these translations are a parody, but Henry Clapp may not have known enough French to realize it and thus may have printed them without a qualm, thinking that they constituted a tribute to Whitman. Even if Clapp had known they were a parody, he would still have printed them, for he had already published parodies of Leaves of Grass in the belief that any attention drawn to Whitman was preferable to silence.

But who was V.H., the supposed author of the translations? Not Victor Hugo, of course, who in all likelihood did not even know of Whitman's existence. His initials, however, were probably deliberately chosen to mislead or intrigue the public. The author must have been a Frenchman living in New York who was perfectly acquainted with Whitman's poetry, for the translations are in impeccable French, even in the slangy passages. If he was a New Yorker, he had an exceptional command of French.

So a problem still remains: who perpetrated the hoax? Charles Cestre, the first holder of the chair of American Literature at the Sorbonne and the first to investigate the mystery, ${ }^{2}$ did not know the answer, and I do not either. Who will solve the puzzle? Almost certainly no one at this late date.

Université de Paris-Sorbonne

Roger Asselineau

\section{NOTES}

1 Henry Clapp was particularly enthusiastic about the 1860 edition of Leaves; see Horace Traubel, With Walt Whitman in Camden (New York: Mitchell Kennerley, 1915), 2:375-376. Thayer \& Eldridge, Whitman's Boston publishers, helped Clapp financially in 1860; see Edwin Haviland Miller, ed., The Correspondence (New York: New York University Press, 1961), 1:55.

2 "Un intermède de la renommée de Walt Whitman en France," Revue AngloAméricaine 13 (December 1935), 136-140. 